\title{
Sistem Pakar Mendiagnosa Penyakit Gagal Jantung Pada Manusia Dengan Menggunakan Metode Certainty Factor Berbasis Web
}

\author{
Sutrisno $^{\mathrm{a} 1}$, Jijon Raphita Sagala ${ }^{\mathrm{a} 2}$ \\ ${ }^{a}$ Program Studi Teknik Informatika, STMIK Pelita Nusantara Jl. St. Iskandar Muda No. 1 Medan, Indonesia \\ ${ }^{1}$ soetrisnobachir07@gmail.com; ${ }^{2}$ sisagala@gmail.com;
}

\section{INFORMASI ARTIKEL}

\section{KataKunci:}

Data Mining

K-Nearest Neighbor

PrediksiKelulusan

\section{ABSTRAK}

Untuk mengatasi penyakit gagal jantung di Rumah Sakit Umum Sultan Sulaiman saat ini masih mengalami beberapa kendala yang menghambat pasien. Diantaranya adalah banyak masyarakat yang tidak perduli akan kesehatanya, kurangnya pengetahuan masyarakat mengenai penyakit gagal jantung, kurangnya tenaga medis di Rumah Sakit Umum Sultan Sulaiman, dan jam kerja dokter yang terbatas. Dengan adanya sistem ini bukan berarti menghilangkan ataupun menggantikan peran dari seorang pakar ahli dalam bidangnya atau dokter spesialis jantung di Rumah Sakit Umum Sultan Sulaiman. Tetapi dengan adanya sistem ini diharapkan pasien dapat mengetahui langsung bagaimana cara mengidentifikasikan jenis penyakit gagal jantung berdasarkan gejala yang dirasakan oleh pasien. Sehingga dengan adanya sistem ini dapat mempermudah dan mempercepat kinerja dalam mendiagnosa awal penyakit gagal jantung yang diderita oleh pasien. Adapun metode yang di terapkan pada sistem adalah metode certainty factor, dengan menentukan 11 gejala dan 2 jenis penyakit, serta menyusun basis aturan dalam menentukan relasi dari tiap gejala sehingga hasil pada perhitungan mencapai hasil yang akurat sebesar $100 \%$. Hasil penelitian menunjukan bahwa metode certainty factor dapat digunakan untuk mendiagnosa penyakit gagal jantung. Sehingga dengan adanya sistem ini dapat menolong masyarakat luas dalam mencari informasi tentang penyakit gagal jantung.

Keywords:

Data Mining

K-Nearest Neighbor

Graduation Prediction

\begin{abstract}
To overcome heart failure at the Sultan Sulaiman General Hospital currently still experiencing several obstacles that hinder patients. Among them are many people who do not care about their health, lack of public knowledge about heart failure, lack of medical personnel at Sultan Sulaiman General Hospital, and limited hours of doctors working. The existence of this system does not mean eliminating or replacing the role of an expert in the field or a cardiologist at the Sultan Sulaiman General Hospital. But with this system, it is hoped that patients can know firsthand how to identify the type of heart failure based on the symptoms felt by the patient. So with this system it can simplify and speed up performance in early diagnosis of heart failure suffered by patients. The method applied to the system is the certainty factor method, by determining 11 symptoms and 2 types of disease, as well as compiling a rule base in determining the relationship of each symptom so that the results in the calculation achieve $100 \%$ accurate results. The results showed that the certainty factor method can be used to diagnose heart failure. So that this system can help the wider community in finding information about heart failure.
\end{abstract}

\section{Pendahuluan}

Seiring dengan perkembangan teknologi di bidang komputer saat ini, baik dalam perangkat keras (hardware) maupun perangkat lunak (software), hampir sebagian besar pekerjaan manusia kini diselesaikan dengan menggunakan sistem yang ada pada komputer. Dengan demikian, komputer dapat dikatakan sebagai salah satu alat bantu manusia dalam menyelesaikan suatu pekerjaan.

Salah satu kegunaan komputer dalam mempermudah menyelesaikan suatu pekerjaan manusia adalah dibidang kesehatan. Di bidang kesehatan, Komputer dapat membantu dalam mendiagnosa berbagai penyakit salah satunya penyakit gagal jantung[2],[3]. Gagal Jantungadalah kondisi kronis ketika jantung tidak dapat memompa darah sebagaimana mestinya, sehingga jantung tidak mampu mengalirkan darah yang cukup ke seluruh tubuh. Untuk mengatasi penyakit gagal jantung di Rumah Sakit Umum Sultan Sulaiman saat ini masih 
mengalami beberapa kendala yang menghambat pasien[4]. Diantaranya adalah banyak masyarakat yang tidak perduli akan kesehatanya, kurangnya pengetahuan masyarakat mengenai penyakit gagal jantung, kurangnya tenaga medis di Rumah Sakit Umum Sultan Sulaiman, dan jam kerja dokter yang terbatas. Sehingga dengan adanya sistem ini dapat mempermudah dan mempercepat kinerja dokter di Rumah Sakit Umum Sultan Sulaiman dalam mendiagnosa awal penyakit gagal jantung yang diderita oleh pasien.

Berdasarkan penelitian terdahulu yang dilakukan oleh sulaksono, [6],[7]yang berjudul "Sistem Pakar Penentuan Penyakit Gagal Jantung Menggunakan Metode Naive Bayes Classifier". Dalam penelitian ini, dia membuat sistem dengan menggunakan metode naive bayes classifier untuk mempermudah pakar jantung dalam mendiagnosa pasien dengan menggunakan gejala - gejala yang dirasakan. Sedangkan menurut penelitian yang sekarang yang berjudul "Sistem Pakar Mendiagnosa Penyakit Gagal Jantung Dengan Menggunakan Metode Certainty Factore Berbasis Web". Dalam penelitian ini penulis menggunakan metode certainty factor untuk mendiagnosa sekaligus memberikan solusi kepada pasien dalam mengetahui penyakit gagal jantung jenis apa yang dideritanya[10].

\section{Metode}

\subsection{Kerangka Kerja Penelitian}

Untuk membantu dalam penyusunan skripsi ini, maka penulis akan membuat kerangka kerja penelitian dengan model waterfall. Kerangka kerja ini merupakan langkah-langkah yang akan dilalui dalam penyelesaian suatu masalah yang akan dibahas nantinya. Adapun kerangka kerja penelitian yang di gunakan sebagai berikut

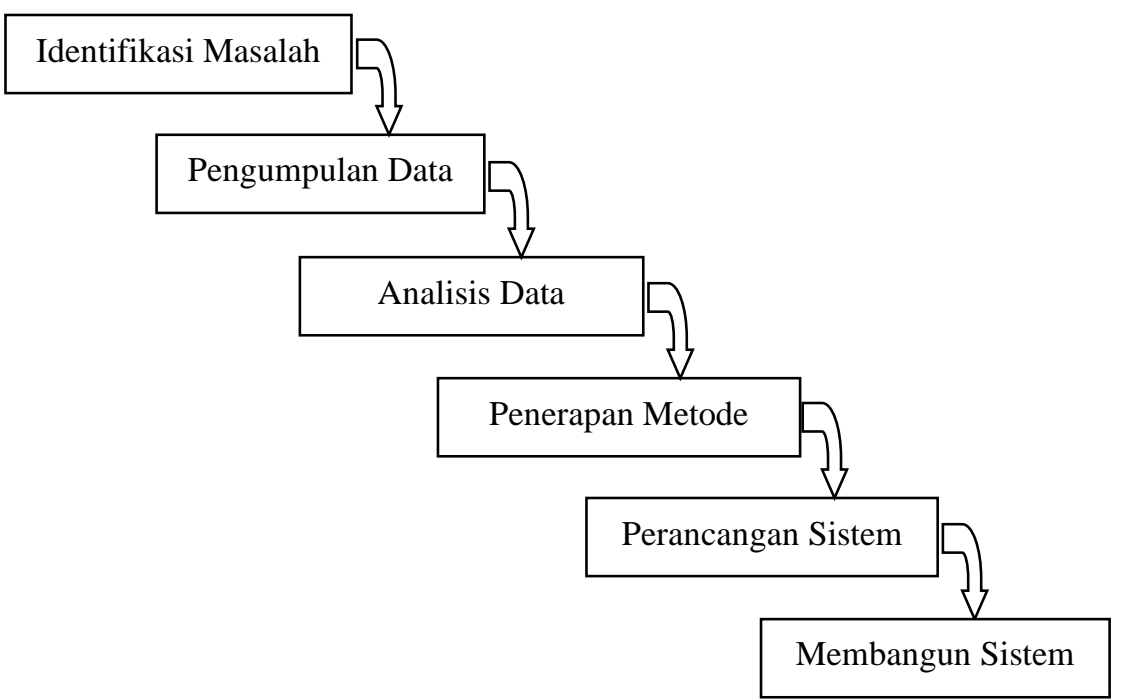

Gambar 1 Kerangka Kerja Penelitian

Berdasarkan kerangka kerja penelitian yang telah digambarkan di atas, maka penulis menguraikan pembahasan masing-masing sebagai berikut :

1. Identifikasi Masalah

Identifikasi masalah dilakukan untuk menentukan topik serta menggali hal yang menjadi tujuan penelitian.

2. Pengumpulan Data

Pengumpulan data dilakukan guna memperoleh informasi yang dibutuhkan dalam rangka mencapai tujuan penelitian. Adapun teknik pengumpulan data tersebut dilakukan dengan :

a. Wawancara

Wawancara dilakukan dengan melontarkan sejumlah pertanyaan secara langsung kepada pakar yang membidangi objek penelitian ini, dalam hal ini yang menjadi pakar adalah dr. Tengku Winda Ardini, Sp.JP yang bertugas di Rumah Sakit Umum Sultan Sulaiman sebagai ahli jantung.

b. Observasi

Dalam hal ini penulis mengamati kondisi atau fenomena yang terjadi pada saat mengumpulkan data.

c. Studi literatur.

Dalam hal ini penulis mencari referensi data berupa buku, jurnal, makalah, dan informasi lainnya melalui internet untuk mendukung penelitian ini. Data yang di dapatkan adalah sampel jenis penyakit, gejala penyakit, dan nilai bobot gejala.

3. Analisis Data 
Pada tahap ini data yang sudah dikumpulkan akan di analisa terlebih dahulu. Berdasarkan literatur yang ada, data-data yang didapat dari hasil wawancara akan disusun kepada sebuah tabel penyakit dan gejala untuk mempermudah pencarian solusi. Adapun data yang didapatkan adalah 2 jenis penyakit gagal jantung yaitu gagal jantung akut, dan gagal jantung kronis, gejala penyakit gagal jantung sebanyak 11 gejala dan masing-masing memiliki bobot serta terdapat basis aturan.

4. Penerapan Metode Certainy Factor

Setelah data dianalisa, maka selanjutnya dilakukan perhitungan metode untuk menyelesaikan permasalahan penelitian yang ada di RSUD Sultan Sulaiman.

5. Perancangan Sistem

Perancangan sistem merupakan rancangan atau desain suatu program yang akan dibangun. Adapun perancangan sistem dibuat dengan menggunakan UML (Unified Modelling Languange). UML terdiri dari activity diagram, use case diagram, dan sequence diagram.

6. Membangun Sistem

Setelah dilakukan perhitungan metode certainty factor dan didapatkan hasil diagnosa secara manual, maka hasil tersebut di implementasikan didalam sebuah sistem yang dibangun. Sistem ini dibangun menggunakan bahasa pemrograman PHP-MYSQL.

\subsection{Metode Certainty Factor}

Certainty factor adalah suatu algoritma yang digunakan ketika menghadapi suatu masalah yang jawabannya tidak pasti dan bisa merupakan probabilitas. Certainty factor menyatakan kepercayaan dalam sebuah kejadian atau suatu fakta atau suatu hipotesis yang berdasarkan bukti atau penilaian pakar. Rumus dari certainty factor adalah sebagai berikut [1]:

$\mathrm{F}(\mathrm{H}, \mathrm{E})=\mathrm{MB}(\mathrm{H}, \mathrm{E})-\mathrm{MD}(\mathrm{H}, \mathrm{E})$

Dimana :

$\mathrm{CF}(\mathrm{H}, \mathrm{E}) \quad=$ Certainty factor hipotesis $\mathrm{H}$ yang dipengaruhi oleh evidence (gejala) $\mathrm{E}$

$\mathrm{MB}(\mathrm{H}, \mathrm{E}) \quad=\quad$ Ukuran kepercayaan (measure of increased belief) terhadap hipotesis $\mathrm{H}$ yang dipengaruhi oleh evidence E

$\mathrm{MD}(\mathrm{H}, \mathrm{E}) \quad=$ Ukuran ketidakpercayaan (measure of increased disbelief) terhadap hipotesis $\mathrm{H}$ yang dipengaruhi oleh evidence $\mathrm{E}$

$\mathrm{H}=$ Hipotesa

$\mathrm{E} \quad=$ Evidence $($ Peristiwa/fakta)

Formulasi dasar digunakan apabila belum ada nilai CF untuk setiap gejala yang menyebabkan penyakit.

Kombinasi certainty factor yang digunakan untuk mendiagnosa penyakit adalah.[5] :

1. Certainty factor untuk gejala tunggal/premis (single premis rules)

2. $\quad$ Frgejala $=\mathrm{CF}\{$ user $\} * \mathrm{CF}[$ pakar $]$

3. Apabila terdapat kaidah dengan kesimpulan yang serupa atau lebih dari satu gejala, maka $\mathrm{CF}$ selanjutnya dihitung dengan persamaan :

4. CFcombine $=\mathrm{CF}$ old $+\mathrm{CFgejala} *(1-\mathrm{CF}$ old $)$

5. Untuk menghitung persentase terhadap penyakit, digunakan persamaan :

CFpersentase $=$ CFcombine $* 100 \%$.

6. Untuk menetukan keterangan faktor keyakinan dari pakar, dapat dilihat dari $\mathrm{CF}$ combine dengan berpedoman dari tabel interprestasi certainty factor [8],[9].

\section{Hasil dan Pembahasan}

\subsection{Implementasi}

Implementasi sistem merupakan proses penerapan implementasi sistem pakar untuk mendiagnosa penyakit gagal jantung dengan menggunakan metode certainty factor. Berikut merupakan penjelasan mengenai form-form yang terdapat dalam sistem yang telah dirancang untuk diimplementasikan.

1. Form Login 


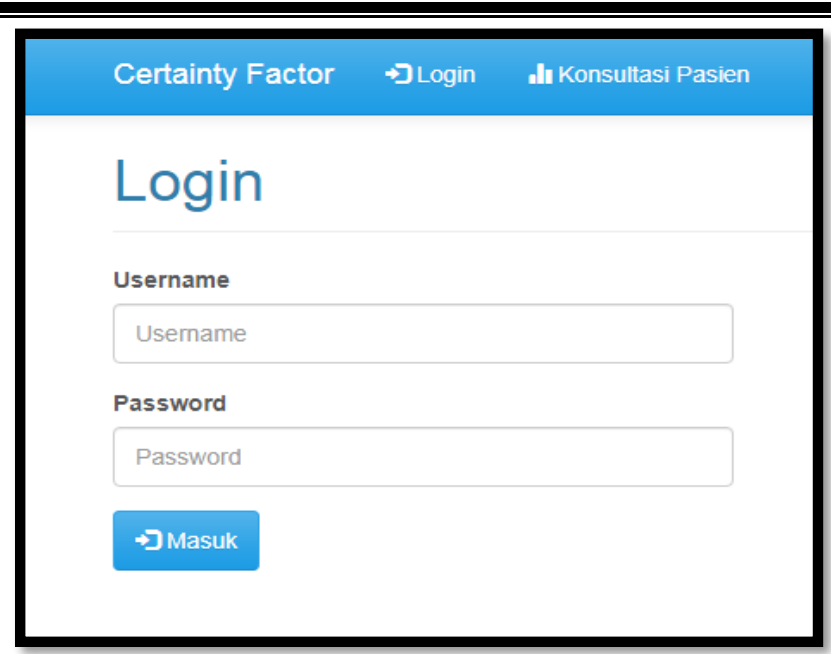

Gambar 2 Form Login

Form login merupakan halaman pertama kali yang akan ditampilkan pada saat sistem dijalankan. Admin diwajibkan untuk memasukkan username dan password yang telah disediakan didalam database untuk dapat menggunakan sistem. Jika benar username dan password yang digunakan maka sistem akan menampilkan form menu utama, sedangkan jika salah maka sistem akan menolak untuk masuk kedalam form menu utama.

2. Form Menu Utama

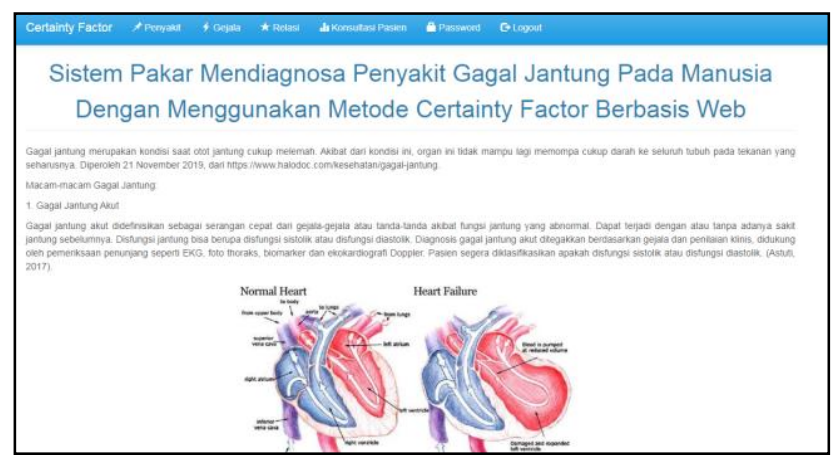

Gambar 3 Form Menu Utama

Form menu utama merupakan halaman yang ditampilkan setelah admin berhasil melakukan proses login masuk kedalam menggunakan username dan password yang telah disediakan didalam database. Form menu utama berisi halaman utama pada sistem dan menu-menu yang dapat digunakan oleh pengguna.

3. Form Data Penyakit

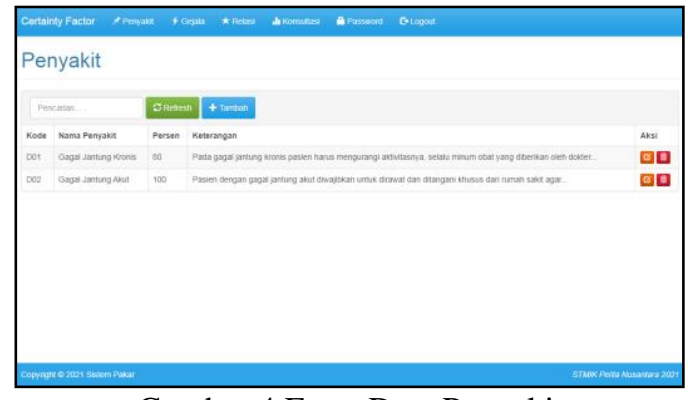

Gambar 4 Form Data Penyakit 
Form ini digunakan oleh admin untuk memasukkan data penyakit berupa Kode Penyakit, Nama Penyakit, Persentase Nilai Bobot Penyakit, Keterangan Penyakit. Kemudian admin dapat melakukan tambah, simpan, edit dan hapus dan sistem akan memproses kedalam database yang telah disediakan.

\section{Form Data Gejala}

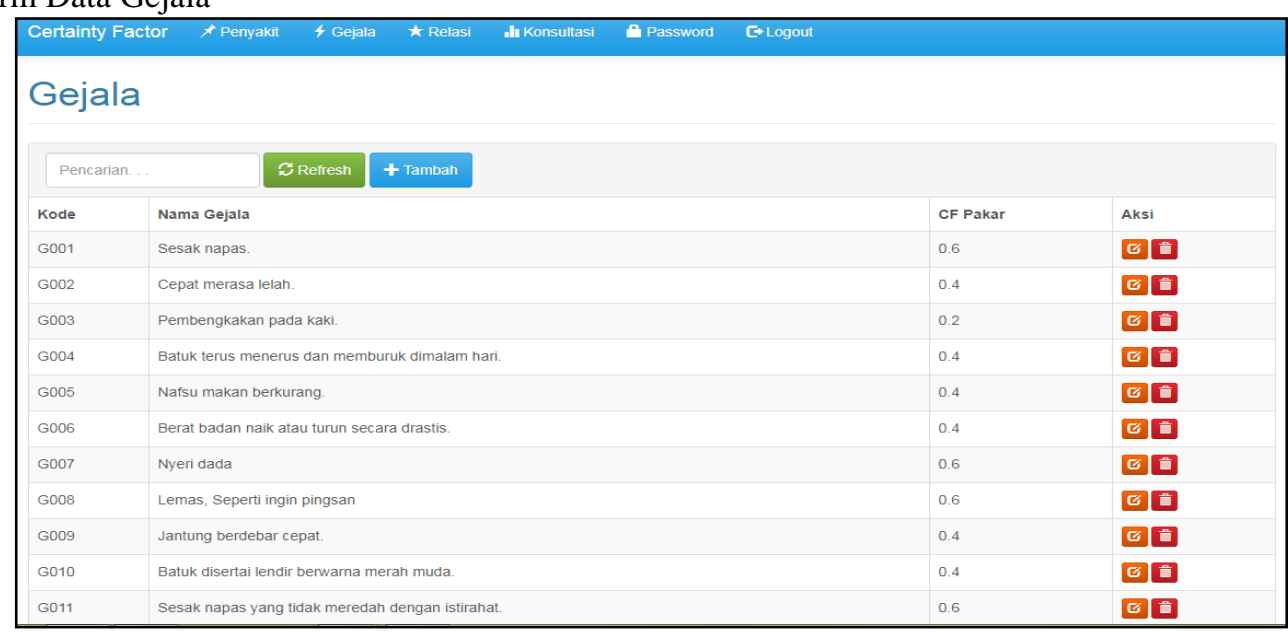

Gambar 5 Form Data Gejala

Form ini digunakan oleh admin untuk memasukkan data gejala berupa Kode Gejala, Nama Gejala, Nilai Bobot Pakar. Kemudian admin dapat melakukan tambah, simpan, edit dan hapus dan sistem akan memproses kedalam database yang telah disediakan.

6. Form Relasi

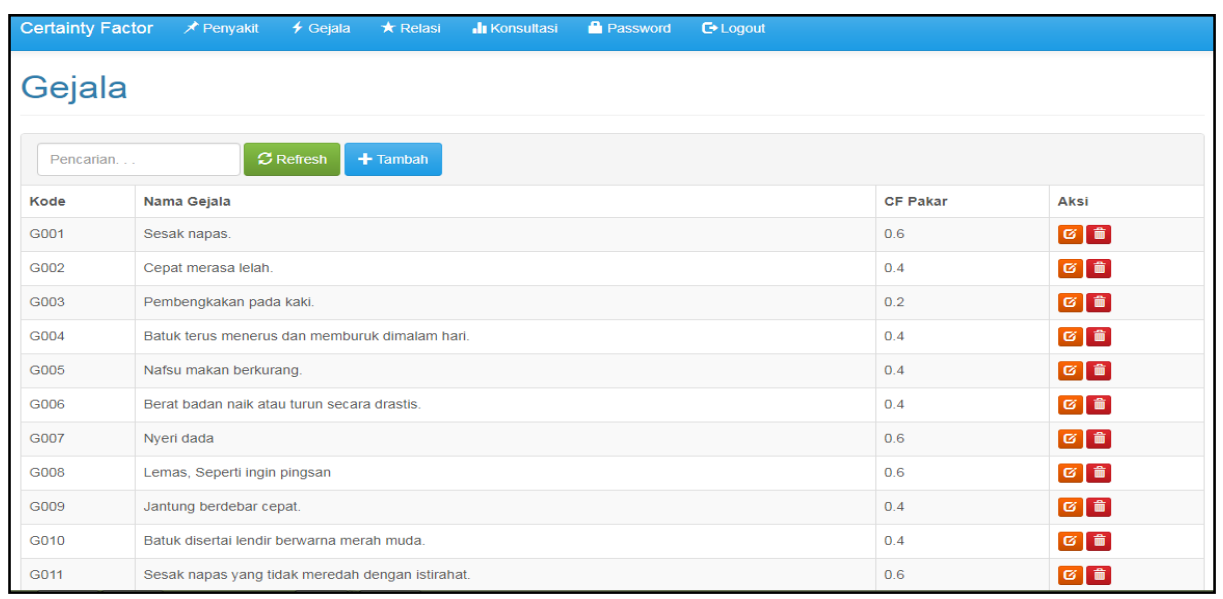

Gambar 6 Form Relasi

Form ini digunakan oleh admin untuk merelasikan data gejala berupa Kode Gejala, Nama Gejala, Nilai Bobot Pakar. Kemudian admin dapat melakukan tambah, simpan, edit dan hapus dan sistem akan memproses kedalam database yang telah disediakan. 
7. Form Konsultasi

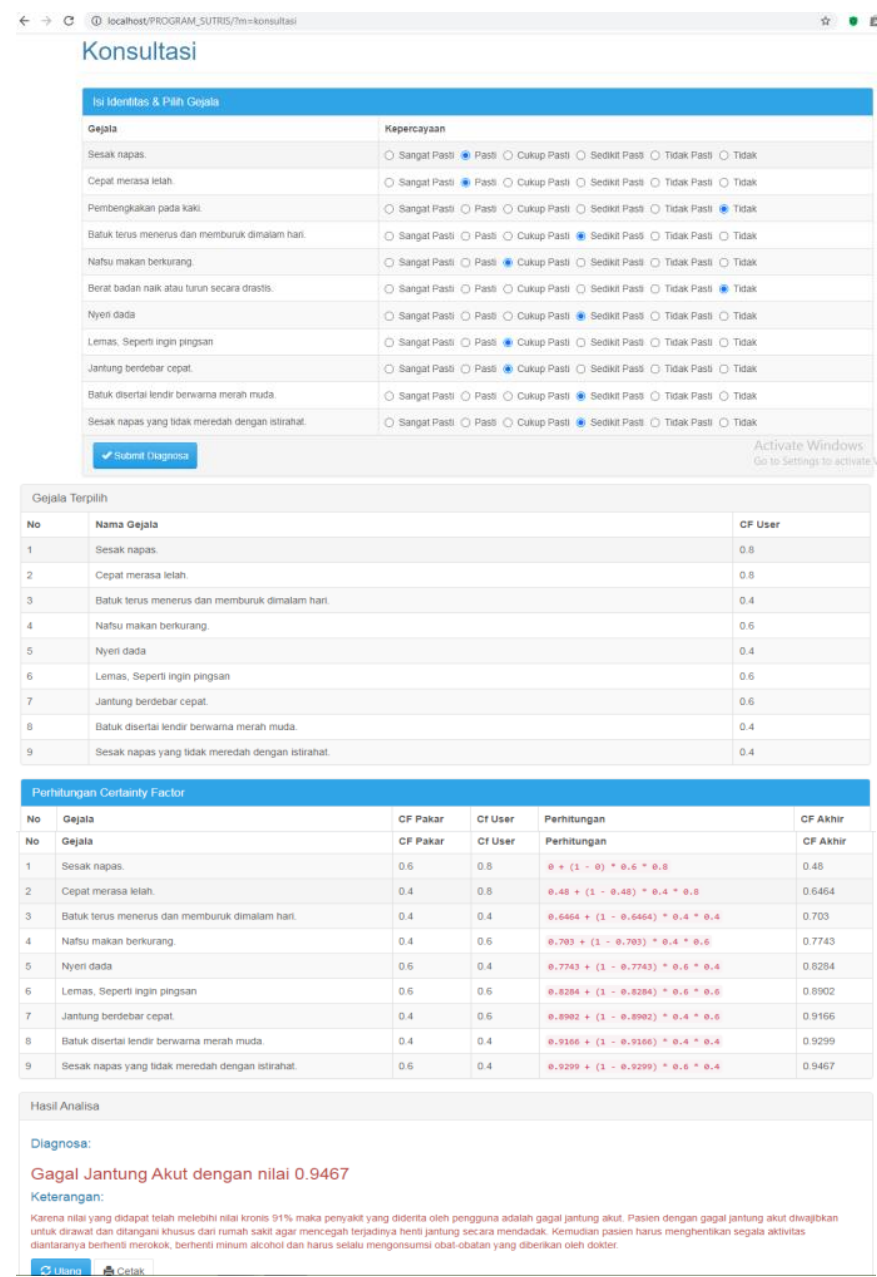

Gambar 7 Proses Konsultasi

Form ini digunakan oleh admin dan user untuk berkonsultasi mengenai penyakit gagal jantung dengan menjawab pertanyaan yang telah disediakan. Cara menjawab pertanyaan tersebut adalah dengan menghitamkan pilihan yang ada pada daftar tingkat kepercayaan pengguna. Isi dari form konsultasi ini berupa Nama Gejala, dan tingkat kepercayaan user.

8. Form Cetak Hasil Konsultasi

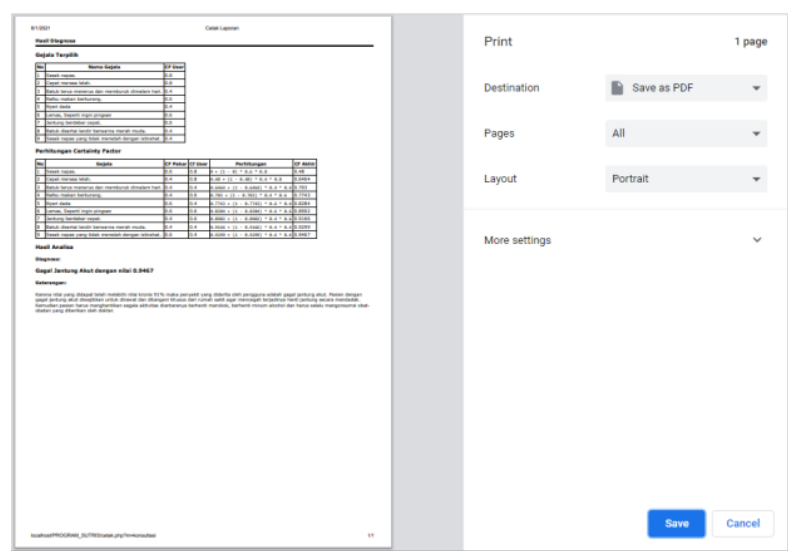

Gambar 8 Cetak Hasil Konsultasi

Pada form cetak hasil konsultasi ini admin dan user bisa melakukan percetakan hasil untuk digunakan sebagi bukti telah mendiagnosa penyakit gagal jantung melalui sistem. 
9. Form Password

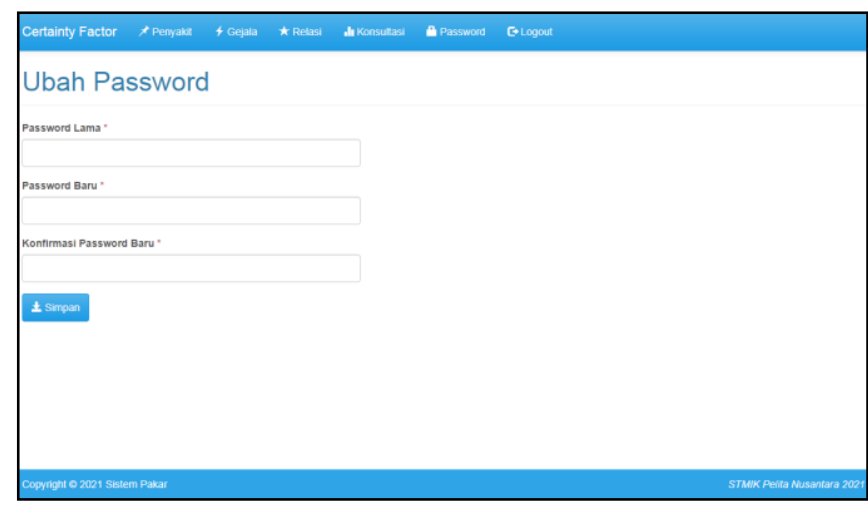

Gambar 9 Form Password

Form ini digunakan oleh admin untuk mengganti password yang lama dengan password yang baru. Isi dari form password ini berupa pertanyaan password lama, password baru, dan konfirmasi password baru.

\subsubsection{Form Logout}

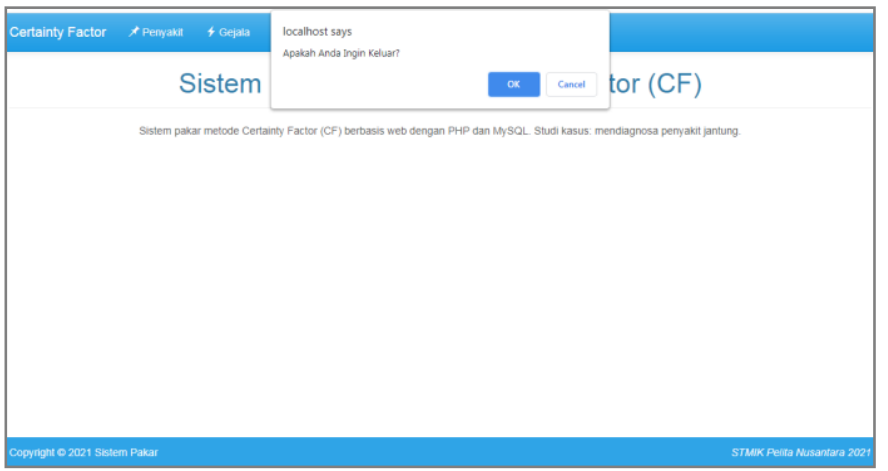

Gambar 10 Form Logout

Form ini digunakan oleh admin untuk keluar langsung dari sistem ke tampilan form login kembali.

\section{Kesimpulan}

Berdasarkan penelitian dan implementasi yang dilakukan pada "Sistem Pakar Mendiagnosa Penyakit Gagal Jantung Pada Manusia Dengan Menggunakan Metode Certainty Factor Berbasis Web".maka dapat diambil kesimpulan sebagai berikut:

1. Penerapan metode certainty factor untuk mendiagnosa penyakit gagal jantung sangat efisien dan dapat mempercepat proses penanganan pasien dalam mendiagnosa awal.

2. Hasil perhitungan sistem dengan manual adalah sama.

3. Implementasi dilakukan dengan menggunakan database sebagai penyimpanan data hasil kombinasi sementara.

\section{Daftar Pustaka}

[1] F. A. Sianturi, M. Informatika, and M. C. Factor, "Analisa Metode Centainty Factor Dalam Mendiagnosa Hama," Mantik Penusa, vol. 3, no. 1, pp. 65-72, 2019.

[2] F. A. Sianturi, "Implementasi Metode Certainty Factor Untuk Diagnosa Kerusakan Komputer," MEANS (Media Informasi Analisa dan Sistem), vol. 4, no. 2, pp. 176-184, 2019.

[3] Fricles Ariwisanto Sianturi, "Analisa metode teorema bayes dalam mendiagnosa keguguran pada ibu hamil berdasarkan jenis makanan," Teknik Informasi dan Komputer (Tekinkom), vol. 2, no. 1, pp. 8792, 2019, [Online]. Available: http://jurnal.murnisadar.ac.id/index.php/Tekinkom/article/view/78

[4] I. Artikel, "Sistem Pakar Mendiagnosa Penyakit Kucing Persia dengan Metode Teorema Bayes," vol. 1, no. 2, pp. 15-24, 2018. 
[5] E. Suwandy, H. Bindan, E. Pranoto, and A. Dharma, "Analisa Metode Random Forest Tree dan KNearest Neighbor dalam Mendeteksi Kanker Serviks," vol. 3, no. 2, pp. 97-101, 2020.

[6] E. Manalu, F. A. Sianturi, and M. R. Manalu, "Penerapan Algoritma Naive Bayes Untuk Memprediksi Jumlah Produksi Barang Berdasarkan Data Persediaan Dan Jumlah Pemesanan Pada Cv . Papadan Mama Pastries," Mantik Penusa, vol. 1, no. 2, pp. 16-21, 2017, [Online]. Available: http://ejurnal.pelitanusantara.ac.id/index.php/mantik/article/view/257

[7] S. P. Tamba, D. R. Hia, D. Prayitna, and A. Tryvaldy, "Pemanfaatan Teknologi Berbasis Mobile Untuk Manajemen Kontrol Nilai Dan Absensi Siswa Pada Mts Al-Ittihadiyah Medan," vol. 2, no. 1, pp. 18 $22,2020$.

[8] V. W. Wati and H. Tusaadiah, "Sistem Pakar Mendeteksi Kerusakan Pada Smartphone Dengan Metode Forward Chaining," Jurnal Sains dan Teknologi: Jurnal Keilmuan dan Aplikasi Teknologi Industri, vol. 17, no. 2, p. 98, 2017, doi: 10.36275/stsp.v17i2.31.

[9] H. T. SIHOTANG, E. Panggabean, and H. Zebua, "Sistem Pakar Mendiagnosa Penyakit Herpes Zoster Dengan Menggunakan Metode Teorema Bayes," vol. 3, no. 3, pp. 192-196, 2019, doi: 10.31227/osf.io/rjqgz.

[10] I. P. Kusumawijaya, "Aplikasi Sistem Pakar Kerusakan Personal Computer Menggunakan Metode Certainty Factor," ICIT Journal, vol. 6, no. 2, pp. 183-194, 2020, doi: 10.33050/icit.v6i2.1115. 